\title{
Sowing War, Reaping Peace: United Nations Resource Development Programs in the Republic of Korea, 1950-1953
}

\section{LISA M. BRADY}

Between 1950 and 1953, the United Nations (UN) undertook two related tasks in Korea: the first was to assist the Republic of Korea in achieving military victory in its conflict with the Democratic People's Republic of Korea; the second was to support postcolonial economic and political reconstruction on the peninsula. In both, the UN promoted the implementation of modern agricultural and resource management practices, directly tying increased domestic farm and forestry productivity to military success. Through the lens of UN development projects, the Korean War, often characterized as a point of rupture, represented less a moment of disjuncture than it did a period of accelerated continuity. This article interweaves environmental, military, and development history to analyze several UN programs in the Republic of Korea between 1950 and 1953, demonstrating that the UN viewed resource development as among the most effective ways to wage and win a war.

Keywords: agriculture, economic development, environmental history, forestry, Korean War, military history, Republic of Korea, United Nations

\section{INTRODUCTION}

To Become a strong, independent nation, what Korea needed most were goats and 1 pigs. And, perhaps, some chickens. This, at least, was the opinion of Thurl Metzger, an American agronomist and farmer who in 1951 worked as the executive director of the charitable organization Heifers for Relief (later Heifer International). Metzger believed that Korea's road to economic growth, agricultural self-sufficiency, and political stability rested on the backs of livestock. He proposed importing 200,000 hatchling eggs and 300 pigs "to improve the quality of Korean chickens and swine" as well as 100 goats "to observe their adaptability to climatic and other conditions in Korea." All stock was to be of pure breed, vaccinated, and free from major stock diseases (UNKRA 1952a, 1). Metzger's recommendations arose in part from a survey he completed in September 1951, done at the behest of the United Nations (UN). Metzger concluded that the best path for Korea's economic recovery and independence involved adopting Western technologies-including animals and seeds-and developing modern agricultural practices (Metzger 1951, 9). 
That the UN contracted with Metzger to undertake such work might be surprising, given the timing. Korea was embroiled in war and had been for over a year; however, it becomes less curious when we understand the UN's purpose for being there in the first place. The UN entered Korea at the end of the Second World War, a time that promised a new era for the peninsula, including self-government and domestic economic growth fueled by natural resource development. Although its primary mission was to repatriate Japanese military and bureaucratic personnel, the UN took an early interest in Korea's economic recovery and development, sending agriculture and industry experts along with military advisors. These specialists, many from Europe and the United States and some retained from the Japanese colonial administration, conducted numerous studies of available natural resources and proposed plans for improving Korea's domestic production, in part to reboot the Korean economy and in part to support the UN's policy aims in Asia. These studies and their recommendations reflected a belief on the part of UN personnel that an industrialized, capitalist economy based on extensive use of well-managed natural and agricultural resources would help to establish democracy in Korea, thus enhancing economic and political stability regionally and globally.

To promote that vision, the UN established the UN Korean Reconstruction Agency (UNKRA) on December 1, 1950. The UN General Assembly identified UNKRA's purpose as twofold, stating in that agency's founding document that it was "convinced that the creation of a United Nations programme of relief and rehabilitation for Korea is necessary both to the maintenance of lasting peace in the area and to the establishment of the economic foundations for the building of a unified and independent nation" (United Nations General Assembly 1950, 33). UNKRA was charged with developing and implementing projects under the joint aegis of the military and civilian arms of the UN in Korea: the United Nations Command and the United Nations Civil Assistance Command-Korea. As its organizational structure and its founding mission reveal, UNKRA's efforts at promoting economic stability were deemed essential for military victory and future domestic development on the peninsula.

This article examines UNKRA's role, as well as that of individuals like Thurl Metzger, in the economic and ecological development of the Republic of Korea during the war years. ${ }^{1}$ In that period, UNKRA attempted to modernize and make more efficient use of the Republic of Korea's natural resources and agricultural practices. Its plans included replacing Korean species-plant and animal, wild and domesticated-with what it deemed to be better species imported from North America, Europe, Japan, Africa, and Central Asia. Efforts concentrated first on agriculture, forestry, and fisheries, and later included building power plants, irrigation schemes, and fertilizer factories. The

\footnotetext{
${ }^{1}$ This article does not address, with very few exceptions, how South Koreans themselves received or participated in UNKRA's development schemes, nor does it evaluate the longer-term success or failure of them. Each of those issues deserves in-depth analysis that cannot be treated adequately in the space allowed here. This article relies predominantly on documents produced by UN personnel or their affiliates held by the United Nations Archives and Records Management Section. The reasons for this are twofold: first, concentrating on a single agency allows more focused understanding of particular development goals, how specific personnel approached questions of resources and the natural environment, and what ideas influenced relevant development decisions; second, UNKRA was fully integrated into the larger UN war effort, thus its projects and experiences help to elucidate the ways in which war, development, and nature intersect.
} 
projects undertaken by UNKRA - conducted in cooperation with and at the behest of the Republic of Korea (ROK) government to promote "relief and economic assistance" (UNKRA 1952e)—shared a remarkable continuity with similar, earlier efforts across Korea beginning with the Kabo Reforms of the 1890s and those under Japanese colonization between 1910 and 1945. But where earlier schemes incorporated reformulation of political structures from the top down and the outside in, with social and economic modernization and more efficient use of resources as end results (Hwang 2016), UNKRA focused its attention on South Korea's agricultural and ecological structures, presuming that capitalism and democracy would follow modern management practices. The pressures of war added urgency to UNKRA's mission, requiring Korea's agro-ecological systems to produce at greater capacity to support both military and civilian needs.

A major challenge facing the UN was the state of Korea's economy and its infrastructure on the eve of war. Japan had formally annexed Korea as a colony in 1910 and spent much of the early twentieth century investing in Korea's industrial and natural resource development, especially between 1938 and 1945 as Japan mobilized for total war. The products and profits associated with such development were not fully reinvested into Korea, however, but were instead exported largely to Japan, its growing empire, and its military. Thus, when the UN entered Korea in 1945, factories, power plants, and other markers of industrialization existed on the peninsula, but a reliable state apparatus, well prepared to guide and direct maintenance and further growth, did not. Moreover, Korea's natural resources, its forests in particular, had been deeply exploited by both the colonial administrators and the local people, leaving them depleted and in precarious circumstances (Fedman 2015). Internal political conflict between those who supported Syngman Rhee's vision of a future fueled by capitalism and those who shared Kim Il-Sung's dedication to the founding of a communist utopia left Korea susceptible to a postcolonial experience fraught with tension and, ultimately, stained by blood. The outbreak of war in June 1950 thus complicated and exacerbated the peninsula's already compromised social, political, and ecological conditions (Brady 2008; Cumings 2005).

Most histories of the Korean War ignore UN efforts to reorganize and modernize the peninsula’s environment (Cumings 1981-90, 2010; Stueck 2002). Similarly, most studies of Korea's economic and agricultural history deal with the war years as an interruption or setback to the nation's development efforts (Brazinsky 2007; Burmeister 1988). As the UN's wartime forestry and agricultural programs demonstrate, however, the military conflict and development strategies were intimately intertwined. Remaking Korea’s agroecological systems was a key component of the UN's approach to both winning the war and building a democratic, capitalist society in South Korea. The developments on the farms and forests-based on efficiency models and modern (Western) management principles - directly benefited the military arm of the UN in Korea as its subsidiary agencies worked in tandem with the United Nations Command. The projects the UN undertook were all premised on a firm acceptance of scientific, technological fixes for economic, social, and ecological challenges. During the crucible of war, where decisions about life and death are paramount, the UN and its partners in the South Korean government nevertheless continued to focus on making the nation's economy run more efficiently and effectively through reordering its agro-ecological systems, by improving pig breeds and goat herds, and on winning the war through sowing seeds. 


\section{Division, Destruction, Development}

Upon Japan's surrender on August 15, 1945, the UN, as the military victors of World War II, took charge of repatriating Japanese colonial and military personnel remaining in Korea. Although the UN ultimately envisioned Korea as a single state (USNSC 1948), early decisions about the peninsula frustrated this ideal. In particular, the United States and the Soviet Union agreed to the 38th parallel as an appropriate boundary for the two administrative zones intended to facilitate decolonization; the Soviet Union was to head the process in the north and the United States in the south. This division reified the growing tensions between the US and the USSR and contributed to the creation of two opposing provisional governments in 1948, the Democratic People's Republic of Korea (DPRK) and the ROK. Immediate and subsequent disagreements within the United Nations Security Council, especially between the United States and the Soviet Union over the future of governance in Korea and the decision in 1949 to seat the representative from the Republic of China (Taiwan) instead of the representative from the newly created People's Republic of China on the Security Council, led to Soviet refusals to participate in or support UN activities in Korea, effectively limiting UN-led reconstruction efforts to the southern half of the peninsula.

Division of the peninsula in 1945 was not just a political problem, it was also an environmental one. Extending south from the main Asian landmass, the peninsula encompasses just under 221,000 square kilometers, including its more than 3,500 islands. Mountains comprise approximately 70 percent of its total area, leaving very little land available for farming; most cultivable land coincides with the lowlands along the western coast of the peninsula, especially south of the Imjin River. Although the DPRK then and now constitutes approximately 55 percent of the peninsula's total area, of that only about one quarter is arable. The ROK thus retained the majority of the agricultural lands, but it lost nearly all access to mineral resources, including deposits of coal, iron, lead, zinc, and copper, as well as the ability to generate heat and power domestically from anything but wood-based products (Hunter 2008; Seekins 1990; Wacaster 2016a, 2016b). This was further exacerbated when, in 1948, the DPRK cut off all access to electric power by the ROK, requiring increased emphasis in the south on building industrial and power-generation infrastructure. While there are a number of major rivers in both the northern and southern parts of the peninsula, the rivers in the south are particularly problematic for energy generation, as they are generally broad and shallow, and exhibit wide seasonal fluctuations in flow (Hunter 2008; Seekins 1990). Such limitations in the ROK led the UN to conduct studies of available resources and develop economic recovery plans, many of which focused on forestry and agricultural development, a logical choice considering the peninsula's geography and the UN's limited reach.

Among the first of these studies focused on South Korea's primary natural resource: trees. Paul Zehngraff, an American forester, headed a UN-sponsored working group survey on South Korean forests in early 1950 and submitted a report to the Program Planning Committee for the Economic Cooperation Administration's Mission to Korea (ECA) on June 23 of that year, just two days before hostilities erupted. He stated in that report that his purpose was "to emphasize the role which forests and forest lands must play in the eventual recovery of South Korea, and the steps essential to forest 
recovery, general land conservation and, consequently, self-sufficiency." Tying the condition of Korea's forests to global trends, Zehngraff wrote, "Because of the accellerated [sic] rate at which other natural resources are dwindling, wood, as a source of raw material, is becoming increasingly essential to the general welfare of humanity. Forest conservation for increased production, therefore, is the wisest investment in the future which any nation can make" (Zehngraff 1950a, 1).

To support his claims, Zehngraff presented statistics on the physical and economic status of South Korea's forests and warned that Korea's forests would "be liquidated" in under twenty years "unless drastic measures are taken in form of temporary implementation and improved management." Without immediate attention, Zehngraff wrote, "early catastrophy $[s i c]$ is inevitable, and other recovery and reconstruction measures will have been in vain” (3). He recommended planting fast-growing species, both native and imported, such as red pine and acacia, on bare ground to mitigate erosion and reestablish forest conditions but suggested that "permanent and more valuable species" be utilized where better growing conditions already existed (7).

The outbreak of war two days after he filed his report served to increase Zehngraff's urgency to see his recommendations instituted. Tanks, long-range artillery, and bomber planes brought even the most remote forestlands under direct fire. Heavy artillery and B-29 bombers had the power to gouge craters in the earth, splintering and uprooting trees. Napalm and white phosphorous engulfed trees, shrubs, and other vegetation in flames. Widespread military destruction of forests and overharvesting by civilians who had little access to fuel other than wood products left Korea's mountains and hillsides less biologically diverse, bereft of protective cover, and highly susceptible to erosion. One study places the amount of forest cover reduction directly attributable to the war at upwards of 60 percent (Jeong et al. 2013). It is not surprising therefore that reforestation became a major focus of UNKRA's work. Despite the setbacks created by the military conflict, Zehngraff noted in a follow-up memo that several improvements had been made, including promotion of peat as an alternative to wood for fuel, direct seeding programs using better-adapted species such as non-native Japanese black larch, and more effective erosion control methods (Zehngraff 1950b, 1-2). He further noted that much of the peninsula's forestry resources existed north of the 38th parallel, making southern efforts at reforestation and forestry management especially important after the war commenced.

Zehngraff's belief that proper forest management formed the foundation for all other reconstruction and development efforts was not unique. According to R. H. Du Pasquier (1951), an agronomist hired by UNKRA, “South Korea’s life depends mostly on production from the soil.... The recovery and development of agriculture and forestry have thus to be considered as the main aims in the rehabilitation plan of this country" (1). Du Pasquier's primary concern was with agricultural development, but he referenced Zengraff's report when he stated, "reafforestation is closely connected with the improvement of agriculture and must be considered as fundamental for the rural economy" (22). Once Korea's forests were rehabilitated, the nation could focus its attention on improving its crops and animals, both of which had been devastated by war. He noted in his report that the war had brought "deep perturbations in the farmland. The two thrusts of the Northern armies ... have inflicted heavy damage on the farmers and to the rural installations." He further reported that livestock numbers had "decreased in such a proportion 
that in many parts the tillage of the land is difficult and the supply of meat and eggs is greatly shortened" (1). His recommendations included reestablishing research stations across the country, conducting soil and disease studies, and "the introduction of foreign varieties ... on a large scale" (38).

Things did not improve immediately. A year after Du Pasquier submitted his report, UNKRA issued a press release stating that the "chicken population has been reduced [between] 75 to 85 per cent since the outbreak of hostilities. It is now so small that, if 120,000 chickens are obtained from these egg shipments, they will increase the national poultry stock by more than 15 percent" (UNKRA 1952c). Several months later, another press release (UNKRA 1952f) noted that "the war in Korea had brought about unprecedented destruction of livestock" and that "the importation of breed animals for rapid increase of livestock, as well as to improve its quality, is vital to the recovery of the country." These sentiments echoed those of Kim Hon Kyu, a rice specialist and adviser to UNCACK and the Food and Agriculture Division of the ECA, who made an impassioned plea both for replenished livestock herds and for support for Korean students to study agriculture and related subjects in the United States (Kim 1952). Kim reported that the cattle population in Korea had decreased by 45 percent between June 25 and December 31, 1950. Dairy cattle and horse numbers each declined by nearly a quarter, hogs and poultry by almost 75 percent, sheep and goats by half, rabbits by 38 percent, and honeybees by 48 percent. In an earlier memo, Kim (1951) averred that because of their low care input and high reproductive traits, goats were a primary need in South Korea, noting that five would "support a family well."

To address the agricultural deficiencies raised in Du Pasquier's report and affirmed by Kim's requests, UNKRA implemented the Heifer Project and the Improved Seed Imports Project. Thurl Metzger, whose assessment of South Korea's animal husbandry opened this article, headed up the first venture. Metzger worked with stock experts in the United States, Canada, and Japan to find suitable goats, pigs, and chickens to supplement South Korea’s dwindling supplies. In August 1952, Metzger reported in a newsletter that initial shipments of livestock to Korea were successful. These included "600 cases of hatching eggs, 297 pure-bred hogs and 95 Saanen goats.” Each case of eggs contained thirty dozen, for a total of eighteen thousand dozen sent to Korea from American chicken breeders that year. The pigs and goats came from Des Moines, Iowa, and San Francisco, California (Metzger 1952). Although most of the animals arrived in good health, they were not exactly what the Koreans had expected, and some controversy arose, especially over the goats (Shaughnessy 1952). Nevertheless, the animals became the basis for new, improved breeding stock in Korea, either to replace Korean breeds or to be interbred with them.

Even more than the status of Korea's livestock, of particular concern was a shortage of fertilizer. According to Dr. Pedro E. Abelarde, an economic affairs officer for the UN Korean Mission, nitrogenous fertilizer had been South Korea's primary import for several years. In his 1952 report to UNKRA, Abelarde noted that prior to the war, there had been efforts to increase domestic production of nitrogen-based fertilizers by building a dedicated plant, but American advisors opposed such plans because they feared "that if Communist forces should conquer South Korea, the plant could easily be converted into a munition [sic] plant." Nevertheless, Abelarde asserted "that climatic conditions, terrain, and population density in the country necessitated an intensified system of 
agricultural production" that "would require both irrigation and heavy utilization of natural and commercial fertilizer" (Abelarde 1952, 2-6). Abelarde further argued that in addition to instituting intensive agricultural practices, the ROK should rehabilitate and expand its water management system to improve irrigation and flood control. He concluded that the projects "would aid in preventing the rapidly progressing erosion of the soil which has been, and still is, a serious problem in the program of rehabilitation of South Korea" (13).

While UNKRA's immediate goal was to increase agricultural yields, a secondary aim was to modernize South Korean agricultural practices through the implementation of scientific research. Both the Heifer Project and the Improved Seed Imports Project were experimental in nature with stated goals of determining which species or varieties would adapt best to "climatic and other conditions in Korea" (UNKRA 1952b, 1952d). There was precedence in the larger region and elsewhere for such climate-based agricultural experiments. The American Institute of Crop Ecology (AICE), "a research organization devoted to problems of plant adaptation and introduction," conducted a series of studies in which regions around the world were compared to "agro-climatological" conditions in North America to help determine what plants might be best suited for introduction in similar climate zones. Such "climatic analogues" were applied to agricultural development in post-WWII Germany, Japan, and China (Hanson 1949; Howe 1948; Thone 1949). In October 1952, the ROK ambassador to the United States Dr. You Chan Yang wrote to General John B. Coulter, then head of UNKRA, asking for such studies to be conducted in Korea: "Such a study, in my opinion—although I am not an expert in agricultural matters-would benefit our country" (You 1952).

A unique aspect of the program was that even as it worked to remake Korea's agroecology to mimic North America's, the AICE project took into account the local environmental conditions. Edwin Henson, a member of AICE's advisory board in 1952, explained the process of developing "climate analogues" and noted that when such studies are completed, "the technician knows what crops are most productive, what varieties of these crops to grow, what machinery will work satisfactorily in the area, the possibilities of irrigation, the insects and disease pests likely to be encountered and the remedial measures required" as well as "many other important factors in advising people of the area on methods designed to restore or improve their production" (Henson 1952). Knowing the climatic analogue theoretically enabled recovery efforts to take effect more quickly than if a full-blown agro-ecological study had to be conducted. Furthermore, promoting high-yield food production would reduce Korea's need to import food and, according to the United Nations Commission for the Unification and Rehabilitation of Korea (1951), "thus allow a larger proportion of the available international funds to be devoted to other forms of Korean relief and reconstruction," a goal established very early in the conflict.

That reconstruction, modernization, and military operations were deeply interconnected in Korea during its war is made clear by a letter written by Chung Yun-tai, an official within the ROK Ministry of Communication. He wrote on September 10, 1952, "While we are fighting against the Communist[s] we also have to rehabilitate our industries," and while the "UN forces are keeping the victory in the front, we should accomplish our rehabilitation work in the rear" (Chung 1952). UNKRA took that mandate seriously. Throughout the war, UNKRA worked to develop South Korea's economy not 
only to support the ROK's war aims, but also to provide the nation with what it believed were the foundations for a strong and successful democracy. In addition to its agricultural and forestry initiatives, UNKRA implemented programs to improve Korea's fisheries, its irrigation and hydroelectric infrastructure, and its industrial base, all toward the end goal of transitioning the ROK into a modern, capitalist nation. At the root of these efforts was the belief in scientific management of natural resources.

The UN worked around the world doing similar projects for similar ends (and still does), but in Korea, the outbreak of war intensified the need for rapid transformation of that nation's agricultural, industrial, and economic infrastructure, making it an excellent case study for understanding the ways the UN and other international organizations attempted to modernize nations through reordering their environments. Korea also provides important insight into warfare as a catalyst for environmental change, not just through combat's destructive capacity, but through the ways individuals and organizations respond to the pressures of war.

\section{Continuity within Chaos}

The war presented unique and far-reaching challenges for UN reconstruction plans, but it did not represent a complete rupture from past or ongoing attempts to introduce modern, scientific management practices to Korea's forests and agricultural resources. As Kyung Moon Hwang and David Fedman have ably demonstrated, such efforts began well before UN intervention in Korea in the mid-twentieth century, even predating similar Japanese colonial policies from 1910 through 1945 (Fedman 2015; Hwang 2016). Attempts to institute scientific resource management began late in the Chosonn dynasty (1392-1910), best represented by the Kabo Reforms of 1894-95 — which fundamentally reorganized the structure of the central Chosŏn administration and its fiscal authorityand in the Kwangmu Land Survey of 1898-1904, which, according to Kim Yong-sop (2005b), intended both to solve the problem of dwindling tax income and to dissipate civil unrest over social and economic disparities, especially between peasants, tenant farmers, and landlords. Each of these reforms, initiated at the behest of Japanese advisors, attempted to make the state apparatus more efficient and effective while at the same time sought to justify the central administration's increased reach and authority. Using both traditional Korean and new Western surveying technologies and methods, the Kwangmu cadastral survey determined the size, shape, location, owner, and cultivator of each land parcel and graded lands according to their potential yield; issued titles for the properties; and established who owed how much in taxes for each parcel surveyed. Crop failures and political challenges, including peasant revolts over land issues and increased foreign intervention, impeded the completion of the Kwangmu survey, but it and its associated project of issuing deeds and titles to lands nevertheless provided extensive data on which later reforms were in part based. This is particularly true for the Land Survey Ordinance undertaken by the Japanese colonial authority between 1910 and 1918, which Hwang argued continued the work of the Kwangmu project, thereby demonstrating “a consistent effort at resource mobilization and the application of ever more administrative (and mobilizational) rationalities" (Hwang 2016, 25-46, quotation on 46; see also Choi 2005; Kim 2005a). 
Chosŏn-era modernization programs were fraught with problems and failed to achieve their ultimate goals, but they were nevertheless important precursors to development projects undertaken by both the Japanese and the UN by establishing the administrative structures within which the later programs would operate. They also set a precedent of prioritizing centralized authority and systematized methods for development. Agriculture, the primary economic sector in Korea during all three periods, became the chief target for such projects. All three administrative regimes desired increased agricultural productivity and introduced strategies based on modern (that is, foreign) farming technologies and techniques. During the late Chosŏn, officials established an agricultural school staffed by instructors from England and supplied with textbooks translated from Japanese (Kim 2005a, 43). Japanese colonial authorities also encouraged agricultural modernization and intensification (Gragert 1994). Lee Hoon Koo noted in his 1936 assessment of Korea's rural economy that although colonial land reform had as its primary function increased tax revenue rather than better agricultural practices, the state did institute agricultural reforms as part of its modernization program, including the importation of new varieties of horses, pigs, chickens, and bees to improve native stock (Lee 1936, 76-83). Kim Yong-sop described a specific development scheme instituted in the 1920s - the Program to Increase Rice Production-that replaced Korean materials and methods with "Japanese rice plants, improved Japanese farming tools, and Japanese chemical fertilizers" (Kim 2005b, 137-39). Finally, Hong Sung-Chan noted that in the late 1930s, a new class of landlords, nongjang, or agricultural estate owners, undertook scientific analysis of their lands to increase productivity, commissioning research institutes to test soil fertility and provide reports on specific methods for improving agricultural techniques (Hong 2005, 185).

Although agricultural productivity was central to modernization and developmental reforms, Korea's other major resource base, forestry, also came under scrutiny (Komeie 2006). With the annexation of Korea by Japan in 1910, significant tracts of royal and undocumented private forested land became property of the colonial state, although provisions for local and traditional use remained an important part of colonial forest management (Fedman 2015). Managing and harvesting forest products became a state affair in 1926 with the creation of Forest Management Stations in the Yalu and Tumen river basins, which according to Lee Hoon Koo reorganized and unified the industry with the goal of making Korea's timber resources "inexhaustible." In addition to managing state-run forests, the colonial administration granted leases to individuals who could then claim ownership if they successfully reforested areas affected by overharvesting (especially near population centers), slash-and-burn agriculture, and traditional land-use patterns that treated the forests as a commons (Lee 1936, 181-88, quotation on 185). Colonial Japanese efforts to improve Korea's forest resources became, according to David Fedman (2015, 180), "a mechanism for re-organizing local society, invigorating private industry, and diffusing Japanese ideas about stewardship, land ownership, and ecological modernity."

Colonial efforts to modernize Korea's natural resource sectors were, of course, selfserving in that the products from the farms and forests ultimately supported Japan's home economy, its imperial expansion, and, beginning in 1931, its massive total-war economy (Gragert 1994; Kim 2005b, 138). After Japan's invasion and occupation of Manchuria in 1931 and during the Second Sino-Japanese War (1937-45), Korea served as a resource and mobilization base, rather than as a site of battle; nevertheless, fifteen years of 
rapid industrialization, with at least seven of those under total-war mobilization conditions, put Korea's resources under immoderate strain, resulting in massive deforestation and over-exploitation of soils and other mineral resources.

The same held true when the peninsula witnessed the direct effects of war between 1950 and 1953. Korea's forests were devastated by military activity, and declined in quantity and quality despite concerted efforts in the south, at least, to maintain some semblance of scientific management and reforestation schemes. Its agricultural lands had to provide not just for a desperate civilian populace, expanded by nearly four million refugees displaced by armed combat and military destruction, but also for the armed forces personnel at the front and in reserve. Moreover, South Korea's fields and forests were expected to produce enough to generate a surplus for trade (primarily with Japan), thereby contributing to the nation's economic development and integrating it into regional and global markets. All of these aspects of Korean resource and economic development during the Korean War continued trends put in place during the final years of the Chosŏn dynasty and expanded under Japanese colonialism.

An examination of UNKRA's policies and programs thus reveals that although the 1950-53 Korean War represented a monumental moment of disruption politically and socially, the agency's development efforts during the conflict served to heighten and reinforce goals that had been in place in Korea for nearly six decades. Like earlier land reform projects, UNKRA aimed at rapid modernization through the efficient use of natural resources and the institution of science-based farming. Over the course of its eight-year organizational life, UNKRA completed hundreds of major projects at over 4,200 sites across South Korea, expending approximately $\$ 146,000,000$, the equivalent to nearly $\$ 1$ billion in 2010 dollars (Lyons 1961, 224; UNARMS, n.d.). Rather than allow the military conflict to disrupt or curtail this agenda, the UN redoubled its efforts, convinced that economic and resource development and use would win the war as well as establish the necessary foundations for peace and a successful future on the Korean peninsula.

\section{Acknowledgments}

I would like to thank participants in the Works in Progress Seminar at the Rachel Carson Center for Environment and Society (Munich, Germany) for valuable feedback on this article, as well as John Lee, David Fedman, Albert Park, and Micah Muscolino for their intellectual support and encouragement. Research for this article was supported in part by an American Society for Environmental History Samuel P. Hayes Research Fellowship and by a Carson Writing Fellowship from the Rachel Carson Center in Munich.

\section{List of References}

\section{Primary Sources}

Abelarde, Pedro E. 1952. "Some Aspects of Korean Economic Rehabilitation." United Nations Korean Reconstruction Agency (UNKRA) Registry Files, series 526, box 17, 
folder 6. United Nations Archives and Records Management Section (UNARMS), New York.

Chung Yun-tai. 1952. Letter to F. B. Silsbee. September 10. UNKRA Registry Files, series 526, box 21, folder 4. UNARMS, New York.

Du Pasquier, R. H. 1951. "Agricultural Report: Recovery and Development of Korean Agricultural Production.” January 14. UNKRA Registry Files, series 526, box 19, folder 6. UNARMS, New York.

Hanson, Herbert C. 1949. "The Agro-climatic Analogue (Homoclime) Technique in Plant Introduction and Distribution of New Selections." Agronomy Journal 41(5): 186-88. UNKRA Registry Files, series 526, box 19, folder 4. UNARMS, New York.

Henson, Edwin R. 1952. Letter to General Clyde L. Hyssong. October 3. UNKRA Registry Files, series 526, box 19, folder 5. UNARMS, New York.

Howe, G. Melvin. 1948. “Agro-climatic Analogues.” Nature 161(4101):983. UNKRA Registry Files, series 526, box 19, folder 4. UNARMS, New York.

KIm Hon Kyu. 1951. "The Necessity of Goat Importation.” September 8. UNKRA Registry Files, series 526, box 20, folder 3. UNARMS, New York.

—. 1952. "Technical Training in Agriculture." September 12. UNKRA Registry Files, series 526, box 20, folder 3. UNARMS, New York.

Metzger, Thurl. 1951. "Korean Report.” September 20. UNKRA Registry Files, series 526, box 20, folder 3. UNARMS, New York.

—. 1952. "Newsletter." August 5. UNKRA Registry Files, series 526, box 20, folder 3. UNARMS, New York.

Shaughnessy, W. K. 1952. Letter to Heifer Project Committee. July 24. UNKRA Registry Files, series 526, box 20, folder 3. UNARMS, New York.

Thone, Frank. 1949. “Climatic Doubles Are Charted." Science Newsletter (August 13):106-7. UNKRA Registry Files, series 526, box 19, folder 4. UNARMS, New York.

United Nations Commission for the Unification and Rehabilitation of Korea. 1951. "Interim Report and Resolution Adopted by the Commission at Its Seventy-First Meeting on 29 April.” UNKRA Registry Files, series 526, box 19, folder 1. UNARMS, New York.

United Nations General Assembly. 1950. "Resolution 410.V: Relief and Rehabilitation of Korea." In Resolutions Adopted by the General Assembly during Its Fifth Session, 31-35. https://unarchives.files.wordpress.com/2012/09/nr006008.pdf (accessed December 17, 2017).

UnKRa (United Nations Korean Reconstruction Agency). 1952a. "Project Agreement, Project No. 1 (UNK-1), Heifer Project.” January 5. UNKRA Registry Files, series 526, box 20, folder 3. UNARMS, New York.

—. 1952b. "Project Agreement, UNKRA Project No. 1 (UNK-1), Heifer Project." February 25. UNKRA Registry Files, series 526, box 19, folder 2. UNARMS, New York.

—. 1952c. "UNKRA and Heifer Project Committee to Send 210,000 Hatching Eggs to Korea." Press Release KQR/299, March 28. UNKRA Registry Files, series 526, box 20, folder 3. UNARMS, New York.

. 1952d. "Project Agreement, UNKRA Project No. 18, Improved Seed Imports." April 7. UNKRA Registry Files, series 526, box 19, folder 2. UNARMS, New York. . 1952e. "Standard Operating Procedure, Number 13." June 9. UNKRA Registry Files, series 526, box 19, folder 1. UNARMS, New York. 
1952f. "UNKRA and Heifer Project Committee to Fly Pigs and Goats to Korea." June 16. UNKRA Registry Files 526, box 20, folder 3. UNARMS, New York.

USNSC (United States National Security Council). 1948. A Report to the President by the National Security Council on the Position of the United States with Respect to Korea. April 2. National Security Archive, Washington, D.C. http://nsarchive.gwu. edu/coldwar/documents/episode-5/02.pdf (accessed December 17, 2017).

You Chan Yang. 1952. Letter to John B. Coulter. October 7. UNKRA Registry Files, series 526, box 19, folder 5. UNARMS, New York.

Zenngraff, P. 1950a. Memorandum to Program Planning Committee. June 23. UNKRA Registry Files, series 526, box 20, folder 11. UNARMS, New York.

- 1950b. Memorandum to Director of Food and Agriculture Division, ECA. July 1. UNKRA Registry Files, series 526, box 20, folder 11. UNARMS, New York.

\section{Secondary Sources}

Brady, Lisa M. 2008. "Life in the DMZ: Turning a Diplomatic Failure into an Environmental Success." Diplomatic History 32(4):585-611.

Brazinsky, Gregg. 2007. Nation Building in South Korea: Koreans, Americans, and the Making of a Democracy. Chapel Hill: University of North Carolina Press.

Burmeister, Larry L. 1988. Research, Realpolitik, and Development in Korea: The State and the Green Revolution. Boulder, Colo.: Westview Press.

Chor Won-kyu. 2005. "The Legalization of Land Rights under the Great Han Empire." In Landlords, Peasants, and Intellectuals in Modern Korea, eds. Pang Kie-chung and Michael D. Shin, 91-128. Ithaca, N.Y.: East Asia Program, Cornell University.

Cumings, Bruce. 1981-90. The Origins of the Korean War. 2 vols. Princeton, N.J.: Princeton University Press.

2005. Korea's Place in the Sun: A Modern History. Rev. ed. New York: W.W. Norton.

2010. The Korean War: A History. New York: Modern Library.

Fedman, David Abraham. 2015. "The Saw and the Seed: Japanese Forestry in Colonial Korea, 1895-1945.” PhD diss., Stanford University.

Gragert, Edwin H. 1994. Landownership under Colonial Rule: Korea’s Japanese Experience, 1900-1935. Honolulu: University of Hawai'i Press.

Hong Sung-Chan. 2005. "The Emergence of New Types of Landlords in the Occupation Period." In Landlords, Peasants, and Intellectuals in Modern Korea, eds. Pang Kiechung and Michael D. Shin, 175-206. Ithaca, N.Y.: East Asia Program, Cornell University.

Hunter, Helen-Louise. 2008. “The Society and Its Environment." In North Korea: A Country Study, ed. Robert L. Worden. 5th ed. Washington, D.C.: Federal Research Division, Library of Congress.

Hwang Kyung Moon. 2016. Rationalizing Korea: The Rise of the Modern State, 18941945. Oakland: University of California Press.

Jeong, Su-Jong, Chang-Hoi Ho, Sung-Deuk Choi, Jinwon Kim, Eun-Ju Lee, and Hyeon-Ju Gim. 2013. "Satellite Data-Based Phenological Evaluation of the Nationwide Reforestation of South Korea.” PLoS ONE 8(3):e58900. doi:10.1371/journal. pone.0058900. 
Kim Yong-sop. 2005a. "The Two Courses of Agrarian Reform in Korea's Modernization." In Landlords, Peasants, and Intellectuals in Modern Korea, eds. Pang Kie-chung and Michael D. Shin, 21-52. Ithaca, N.Y.: East Asia Program, Cornell University.

— 2005b. "The Landlord System and the Agricultural Economy during the Japanese Occupation Period." In Landlords, Peasants, and Intellectuals in Modern Korea, eds. Pang Kie-chung and Michael D. Shin, 131-74. Ithaca, N.Y.: East Asia Program, Cornell University.

Komeie Taisaku. 2006. "Colonial Environmentalism and Shifting Cultivation in Korea: Japanese Mapping, Research, and Representation.” Geographical Review of Japan 79(12):664-79.

LeE Hoon Koo. 1936. Land Utilization and Rural Economy in Korea. Chicago: University of Chicago Press.

Lyons, Gene Martin. 1961. Military Policy and Economic Aid: The Korean Case, 1950 1953. Columbus: Ohio State University Press.

Seekins, Donald M. 1990. "The Society and Its Environment." In South Korea: A Country Study, eds. Andrea Matles Savada and William Shaw. 4th ed. Washington, D.C.: Federal Research Division, Library of Congress.

Stueck, William W. 2002. Rethinking the Korean War: A New Diplomatic and Strategic History. Princeton, N.J.: Princeton University Press.

Unarms (United Nations Archives and Records Management Section). n.d. "The United Nations Korean Reconstruction Agency: About UNKRA." https://unarchives.wordpress.com/about-unkral (accessed October 25, 2016).

WaCaster, Susan. 2016a. U.S. Geological Survey Minerals Yearbook-2014: North Korea [Advanced Release] 15.4. Washington, D.C.: US Department of Interior. . 2016b. U.S. Geological Survey Minerals Yearbook—2014: Republic of Korea [Advanced Release] 15.7. Washington, D.C.: US Department of Interior. 